\title{
CHARACTERISTICS OF LIGHTWEIGHT COMPOSITE WALL PANELS WITH POLYPROPYLENE FIBRES
}

\author{
S.Geetha ${ }^{* 1}$, M.Selvakumar ${ }^{2}$ \\ ${ }^{*}$ Corresponding author, Professors, Department of Civil Engineering,Rajalakshmi Engineering College, Thandalam, \\ Chennai-602 105, Tamilnadu, India, Telephone :+919443426577 Fax: 9144 37181113,
}

geetha.s@rajalakshmi.edu.in

\begin{abstract}
Aerated concrete is a type of lightweight concrete. The use of lightweight concrete offers many advantages like reduction in dead load resulting in economical sections and good thermal insulaing properties. Aerated concrete is produced by using aerating agents like aluminium powder and hydrogen peroxide. The density of aerated concrete ranges from $400-1800 \mathrm{~kg} / \mathrm{m}^{3}$. Commercially available lightweight foam concrete blocks have been used extensively in the construction industry for infill walls.The compressive strength of these blocks ranges from 4-6 MPa. This paper deals with the characteristics of aerated concrete reinforced with polypropylene fibres for use as structural walls. Fly ash and bottom ash which are the byproducts from thermal power plants have been used as replacement for cement and sand. A compressive strength of $12 \mathrm{MPa}$ and flexural strength of $3.87 \mathrm{MPa}$ was achieved. The density of the blocks varied from $514-857 \mathrm{~kg} / \mathrm{m}^{3}$. The sorptivity ranged between $0.1-$ $0.25 \mathrm{~mm} / \mathrm{min}^{0.5}$. The experimental trials were designed using Central composite design and multiple optimisation was also carried out for higher strength and lower sorptivity.
\end{abstract}

Keywords: aeration, strength, porosity, density, sorptivit.

****.

\section{INTRODUCTION}

Aerated concrete is a lightweight concrete which can be used as blocks for infill walls of framed structures. The process of aeration is accomplished by introducing an aerating agent like aluminium powder or hydrogen peroxide which liberates hydrogen gas forming a porous structure due to the formation of air voids in the matrix. As a result, the density of aerated concrete ranges from 500 to $1200 \mathrm{~kg} / \mathrm{m}^{3}$ which is very low when compared to the conventional concrete, which has a density of $2400 \mathrm{~kg} / \mathrm{m}^{3}$. The advantages of using aerated concrete in construction, includes reduction in dead load resulting in economical sections, good thermal and acoustical insulation due to the porous nature and easy handling of the material. The properties of conventional concrete have been improved by the use of different fibres like steel fibres, polypropylene fibres, natural fibres and other synthetic fibres. The ability of fibres to reduce brittleness and to support load even after cracking has positive effect on structural performance of concrete. Fibre reinforced concrete is mostly used for concrete pavements and some research has been carried out on beams, slabs and walls. Steel fibre reinforced concrete (SFRC) is more ductile than any other fibre reinforced concrete. But it can be used in application where there is no corrosion. Synthetic fibres like polypropylene fibre reinforced concrete are gaining popularity due to its low cost and non-corrosive nature. One more disadvantage of using steel fibres is that it requires more cementitious material than conventional concrete due to large specific surface of the steel fibres and there is balling effect during the mixing of SFRC. As the amount of steel fibers increases, the slump and air content of the concrete will decrease. Polypropylene is a synthetic hydrocarbon polymer material, first introduced in 1957 [1]. It is adapted from the textile industry which has been added to plain cement concrete in an attempt to improve the performance of concrete. Currently polypropylene is the most widely used synthetic fibers for paving applications [2]. Polypropylene is available in two forms, monofilament fibers and film fibers. Discrete fibres have been used by many researchers $[3,4]$ to improve the ductility of concrete. It has been found that the use of fibres in concrete is an economical way to convert the cementitious product to a tough ductile product $[5,6]$. Frequently used synthetic fibres in concrete are acrylic, polyethylene and polypropylene fibres. Other type of fibres used in concrete includes steel, glass, carbon and Kevlar [7]. The most important fibre parameters which affect the mechanical behaviour of the composites are geometry, distribution, orientation and volumetric proportion of fibres in the matrix $[3,4]$. Unreinforced mortar and concrete lose their load carrying capacity almost immediately after formation of the first crack in the matrix. Addition of fibres increases the toughness of the cement matrix significantly. This performance improvement of fiber reinforced concrete can be attributed to the point that fibers resist crack generation [8, 9]. Addition of polypropylene and nylon fibres to plain concrete have improved the splitting tensile strength, first crack strength and impact resistance[10]. It was observed that by the addition of $0.1 \%$ of polypropylene fibre to concrete the flexural toughness of the concrete increased by $44 \%$. The upper limit volume fraction of polypropylene fibers in cement composites was found to be $0.3 \%$ by cement weight and after an increase in this portion, 
mechanical and physical properties were found to decrease due to ball formation of fibers in the matrix during mixing $[3,9]$. This study presents a comprehensive experimental data and statistical analysis regarding the effects of adding polypropylene fibers with different volume fractions on the physical and mechanical properties of aerated concrete.

\section{MATERIALS \& METHODOLOGY}

\subsection{Materials}

The materials used for the production of fibre reinforced aerated concrete are Portland cement of 53 grade, aluminium powder of grade Conc-95 (the specificatins are given in Table-1), sand, fly ash and bottom ash having the properties as given in Table-2 obtained from Neyveli Lignite Corporation. Polypropylene fibres used in the study are 100 percent virgin homopolymer polypropylene multifilament fibers. The properties of polypropylene fibres used in this atudy are given in Table-3.

\subsection{Methodology}

There are several components involved in the making of fibre reinforced aerated concrete like fly ash, bottom ash, aluminium powder, steel fibres and water/cement (W/C) ratio. Conventional method of experimentation considers only one factor at a time and a series of experiments are conducted sequentially varying the parameters. This method does not explain the influence of any factor and significance of interaction between the factors on the response. Statistically based experimental design techniques are much useful to plan the experimental trials and to reduce the number of trials when there are a number of controllable variables. Central composite design of response surface methodology has been used in this study to design the experiments and ANOVA analysis has been done to check the significance of the experimental data. The use of designed experiments helps to identify the variables and their interaction effects that have significant influence on the response. Conducting experiments based on the experimental design helps in deriving meaningful conclusions. It is also possible to find the optimal combination of the various components for the desired response. The limits of each component were decided based on preliminary trials and were used to design the experimental runs. Each combination was carried out for two trials and the mean value was adopted. The mortar mix was prepared using Portland cement of grade 53, fine aggregate passing 600 micron sieve, fly ash, lime powder, bottom ash and polypropylene fibres. These ingredients were dry mixed in a mortar mixer for 3 minutes. Fly ash and bottom ash were used as partial replacement of cement and sand respectively. Aluminium powder was mixed with the mixing water and added to the dry mix and mixed for 2 minutes. To improve the workability of the mortar mix superplasticiser (ECMAPLAST) was used as $0.7 \%$ by weight of the binding material. After few minutes, the mix started to aerate resulting in increase in volume as shown in fig-1. The aeration process continued for some time. After a stage when the mix stopped to increase in volume the top portion was leveled using a sharp knife and the mix was allowed to set (fig-2). The next day the specimens were demoulded and subjected to steam curing at $100^{\circ} \mathrm{C}$ for 24 hours. Cubes of size $15 \mathrm{~cm} \times 15 \mathrm{~cm}$ were cast for determining the compressive strength.

\section{RESULTS AND DISCUSSIONS:}

\subsection{Density}

Density is the main factor governing lightweight concrete. The density of the aerated concrete varied from 514 to 857 $\mathrm{kg} / \mathrm{m}^{3}$. This density is very less when compared to the conventional concrete which has a density of $2400 \mathrm{~kg} / \mathrm{m}^{3}$. This reduction in density is attributed to the porous structure as a result of air voids that are formed by air entrapment during the aeration process.

The response surface for density of aerated concrete with variation in fibre and fly ash content are shown in Fig-3. For a constant fibre ratio there was very minimum increase in density, but for a constant fly ash content increase in poly propylene fibres increased the density from 514 to 857 $\mathrm{kg} / \mathrm{m}^{3}$. Fly ash reacts with $\mathrm{Ca}(\mathrm{OH})_{2}$ and cement to form hydration products which are shown in the SEM images in Fig-6.The formation of the hydration products is evident from the XRD (Fig-7). The response surface in Fig-4 shows that as the aluminium powder dosage was increased to $0.35 \%$ there was reduction in density from $857 \mathrm{~kg} / \mathrm{m}^{3}$ to 771 $\mathrm{kg} / \mathrm{m}^{3}$ with $0.5 \%$ fibre content. The density reduced with addition of bottom ash as replacement for sand (Fig-5). Bottom ash is a porous material with specific gravity of 1.84 when compared to sand with a specific gravity of 2.6 to 2.7 . Addition of bottom ash reduced the density from $857 \mathrm{~kg} / \mathrm{m}^{3}$ to $685 \mathrm{~kg} / \mathrm{m}^{3}$ even when there was maximum fibre content.

\subsection{Compressive strength}

Compressive strength was tested on $15 \mathrm{~cm}$ cube after curing the cubes at $100^{\circ} \mathrm{C}$ for 24 hours. It was observed that there was increase in strength with addition of bottom ash as sand replacement as bottom ash contains silica which will react with calcium in cement and $\mathrm{Ca}(\mathrm{OH})_{2}$ to form additional hydration products as a result of the pozzolanic activity. However there were some unburnt carbon particles that were present in the bottom ash which is attributed to the reduction in strength from $12 \mathrm{MPa}$ to $8 \mathrm{MPa}$ even with addition of fibres to $0.5 \%$. Similarly the compressive strength was observed to reduce from $12.24 \mathrm{MPa}$ to 9.18 $\mathrm{MPa}$ with $0.35 \%$ aluminium powder content when the fibre content was $0.5 \%$. This is due to excessive aeration which might have resulted in more pores leading to reduction in strength.

Fly ash addition enhanced the compressive strength due to the formation of more hydration products as a result of the pozzolanic activity which is shown in the XRD and SEM images. 


\section{MULTIPLE OPTIMIZATIONS}

As the production of fibre reinforced aerated concrete is a multivariable process, optimization was done for the range of factors used in the experimental investigation.

The criteria adopted for the multiple optimizations were maximum strength with minimum density and sorptivity. The optimized values are summarised in Table-4. For each combination of the optimized level, aerated concrete specimens were cast and the tests were carried out. The results of the predicted and observed values are presented in Table-5. Wall panels of size $1 \mathrm{~m} \times 0.5 \mathrm{~m}$ were cast for the optimized values. The wall panels were steam cured at $100^{\circ}$ C for 24 hours (Fig-11) and tested for compressive strength in the reaction frame (Fig-12). The load vs deflection curve for the wall panel is given in Fig-13. The maximum load was $350 \mathrm{kN}$ and the maximum lateral deflection was 4.8 $\mathrm{mm}$.

\section{CONCLUSION}

The properties of polypropylene fibre reinforced aerated concrete were found to be satisfactory superior to conventional aerated concrete. The steam curing process facilitates the use of the material for prefabricated structural element. The following are the conclusions from this work:

1. The by-products from thermal power plant (fly ash and bottom ash) have a potential use as cement and sand replacement in the making of aerated concrete. It was observed that the aeration process was enhanced with the addition of these materials.

2. Polypropylene fibres can be successively used in aerated concrete to enhance the strength characteristics.

3. The wall panels obtained by the optimised mix proportion have sufficient strength and finds potential use in precast construction industry.

\section{ACKNOWLEDGEMENT}

The authors hereby acknowledge DRDO (DMSRDE) for the financial support for the CARS project (TR/0569/CARS PROJECT-72) on "Development of Fiber Reinforced
Aerated Concretes with Epoxy Coating for Structural Panel Applications".

\section{REFERENCES:}

1. Balagruru,P.and Ramakrishnan,V.,"Mechanical Properties of Superplasticized Fiber Reinforced Concrete Developed for Bridge Decks and Highway Pavements," ACI Publication No. SP-93, 1986, pp. 563-584,

2. Naaman, A. E., Shah,S. P., and Throne, J.L., "Some Developments in Polypropylene Fibers for Concrete," ACI Publication No. SP 81, 1984, pp. 375-396.

3. Libre Nicolas A., Shekarchi M., Mahoutian M., and Soroushian P., "Mechanical properties of hybrid fiber reinforced lightweight aggregate concrete made with natural pumice", Construction and Building Materials, V. 25, 2011, pp. 2458-2464.

4. Ritchie AGB, Kayali O., The effects of fibre reinforcement on lightweight aggregate concrete. In: Neville A, editor. Proceedings of RILEM Symposium on Fibre Reinforced Cement and Concrete, the Construction Press Ltd; 1975, pp. 247-56.

5. Bentur A., and Mindess S., "Fiber Reinforced Cementitious Composites" 2nd edition New York, Taylor \& Francis, Essex, UK, 2007, p.11-235.

6. Kayali O., Haque M.N., and Zhu B., Some characteristics of high strength fiber reinforced lightweight aggregate concrete, Cement \& Concrete Composites, V. 25 (2), 2003, pp.207-213

7. Dong, J Kim., Antoine E. N., and Sherif E.T., "Comparative flexural behavior of four fiber reinforced cementitious composites", Cement \& Concrete Composites, V.30 (10), 2008, pp. 917-928.

8. Andrzej MB. “Cement-Based Composites'2nd edition New York, Taylor \& Francis, 2009.

9. Bagherzadeh R., Sadeghi A.H., and Latifi M.,Utilizing, "Polypropylene Fibers to Improve Physical and Mechanical Properties of Concrete", Textile Research Journal, V. 82(1), 2011, pp. 88-96.

10. Song P. S., Hwang S., and Sheu B. C., "Strength properties of nylon- and polypropylene-fiber reinforced concretes", Cement And Concrete Research, V. 35, 2005, pp. 1546-1550.

Table-1 Specifications of Aluminium powder

\begin{tabular}{|l|l|}
\hline Characteristics: & Conc-95 \\
\hline Volatile Matter \% (max) & 0.5 \\
\hline Metallic Aluminium Content (min) & 90 \\
\hline Density gm/cc & $0.18-0.22$ \\
\hline Average Particle Size & $25 \mu$ \\
\hline Sieve Analysis: & \\
\hline Retained on $180 \mu$ & $1 \%(\max )$ \\
\hline Passing through $45 \mu$ & $>80 \%$ \\
\hline $\begin{array}{l}\text { Gas Reactivity test with Y for } 0.07 \text { GN of Aluminium } \\
\text { Powder at } 25^{\circ} \mathrm{C}\end{array}$ & $70-75 \mathrm{ml}$ of gas evolution within 16 minutes \\
\hline Water Miscibility Test & 100 \\
\hline
\end{tabular}


Table-2 Properties of Class- C fly ash and bottom ash

\begin{tabular}{|c|c|c|}
\hline \multicolumn{3}{|l|}{ Physical properties: } \\
\hline & Fly ash & Bottom ash \\
\hline Specific gravity & 2.64 & 1.84 \\
\hline Fineness, $\left(\mathrm{m}^{2} / \mathrm{kg}\right)$ & 414 & 212 \\
\hline \multicolumn{3}{|c|}{ Chemical properties (\% by mass) } \\
\hline Silicon dioxide $\left(\mathrm{SiO}_{2}\right), \%$ & 31.52 & 30.25 \\
\hline Calcium Oxide $(\mathrm{CaO}), \%$ & 19.2 & 18.23 \\
\hline Alumina $\left(\mathrm{Al}_{2} \mathrm{O}_{3}\right), \%$ & 29.2 & 31.16 \\
\hline Ferric Oxide $\left(\mathrm{Fe}_{2} \mathrm{O}_{3}\right), \%$ & 8.54 & 7.81 \\
\hline Magnesia $(\mathrm{MgO}), \%$ & 3.21 & 2.31 \\
\hline Sodium Oxide $\left(\mathrm{Na}_{2} \mathrm{O}\right), \%$ & 0.84 & 1.02 \\
\hline Potassium Oxide $\left(\mathrm{K}_{2} \mathrm{O}\right), \%$ & 0.13 & 0.15 \\
\hline Sulphuric anhydride $\left(\mathrm{SO}_{3}\right), \%$ & 4.32 & 3.52 \\
\hline Manganese Oxide $(\mathrm{MnO}), \%$ & 0.02 & 0.03 \\
\hline Loss on Ignition, $\%$ & 3.02 & 5.52 \\
\hline
\end{tabular}

Table-3 Properties of polypropylene fibres

\begin{tabular}{|c|c|c|c|}
\hline Absorption & Nil & Melt Point & $324^{\circ} \mathrm{F}$ \\
\hline Specific Gravity & 0.91 & Ignition Point & $1100^{\circ} \mathrm{F}$ \\
\hline Fiber Length & Graded & Thermal & Low \\
\hline
\end{tabular}

Table-4 Optimized Values

\begin{tabular}{|l|l|l|l|l|}
\hline $\begin{array}{l}\text { Al } \\
\text { powder }\end{array}$ & W/C & $\begin{array}{l}\text { polypropylene } \\
\text { fibres }\end{array}$ & Fly ash & $\begin{array}{l}\text { Bottom } \\
\text { ash }\end{array}$ \\
\hline 0.28 & 0.50 & 0.51 & 12.4 & 10.2 \\
\hline
\end{tabular}

Table-5 Predicted and Observed Results

\begin{tabular}{|l|l|l|l|l|}
\hline & $\begin{array}{l}\text { Compressive } \\
\text { Strength(MPa) }\end{array}$ & $\begin{array}{l}\text { Flexural Strength } \\
(\mathrm{MPa})\end{array}$ & $\begin{array}{l}\text { Sorptivity } \\
\left(\mathrm{kg} / \mathrm{mm}^{2} / \mathrm{min}^{0.5}\right)\end{array}$ & $\begin{array}{l}\text { Density } \\
\left(\mathrm{kg} / \mathrm{m}^{3}\right)\end{array}$ \\
\hline Predicted & 11.72 & 1.7 & 0.05 & 648.2 \\
\hline Observed & 12.34 & 2.87 & 0.16 & 892.3 \\
\hline
\end{tabular}

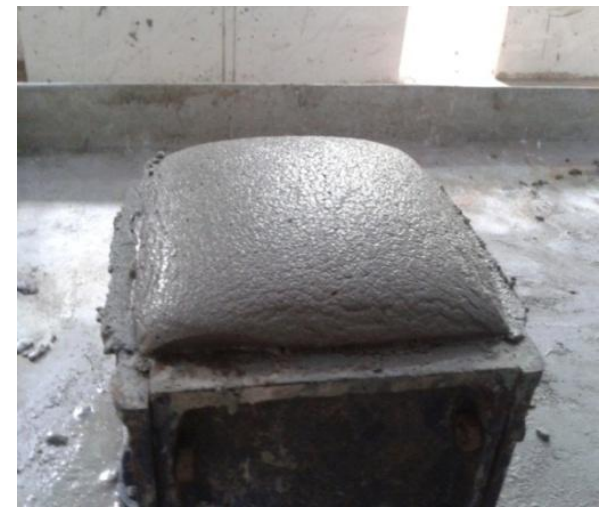

Fig-1 Aeration of fresh mortar mix

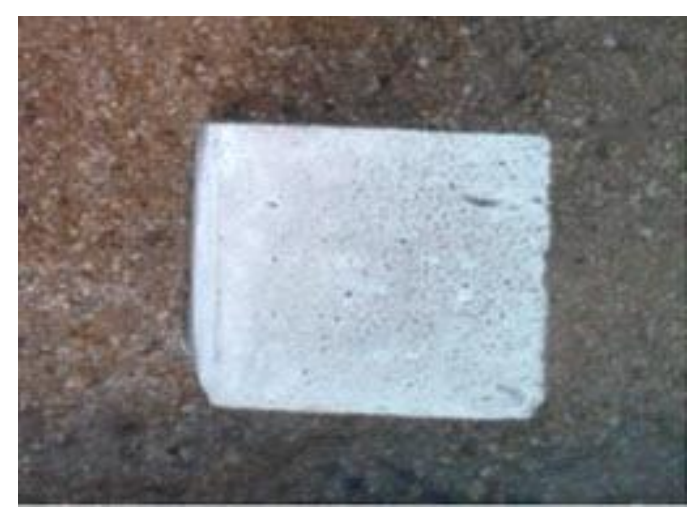

Fig-2 Hardened aerated concrete 


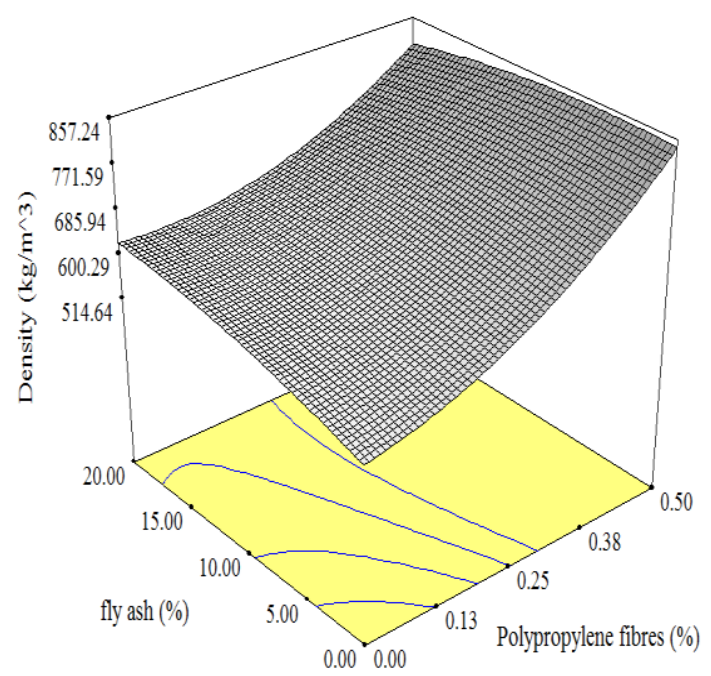

Fig-3 Response surface for density with fibres and fly ash

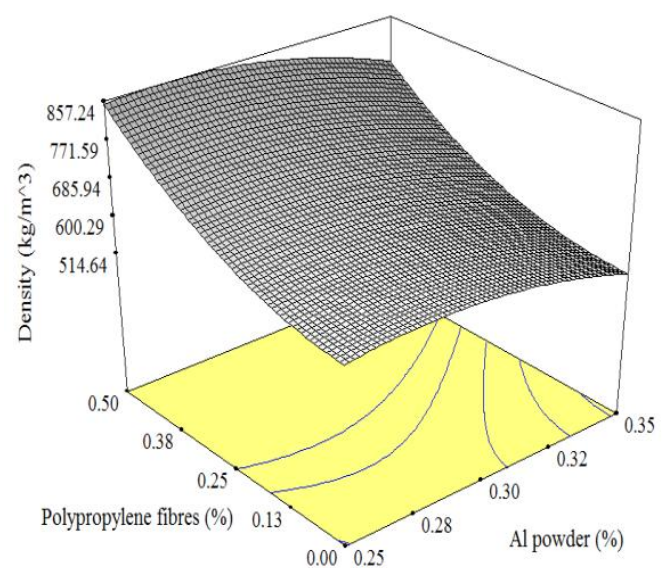

Fig-4 Response surface for density with fibres and $\mathrm{Al}$ powder

q - quartz $\left(\mathrm{SiO}_{2}\right)$, h- hematite $\left(\mathrm{Fe}_{2} \mathrm{O}_{3}\right), \mathrm{m}$ magnetite $\left(\mathrm{Fe}_{3} \mathrm{O}_{4}\right), \mathrm{c}_{2} \mathrm{~S}$ - di calcium silicate $\left(\mathrm{Ca}_{2} \mathrm{SiO}_{4}\right)$, csh - calcium silicate hydrate $\mathrm{Ca}_{3}(\mathrm{OH})_{2} \mathrm{Si}_{16} .4 \mathrm{H}_{2} \mathrm{O}$, a- anhydrate $\mathrm{CaSO}_{4}$, e ettringite $\left(\mathrm{Ca}_{6} \mathrm{Al}_{2}\left(\mathrm{SO}_{4}, \mathrm{SiO}_{4}, \mathrm{CO}_{3}\right)_{3}(\mathrm{OH})\right.$
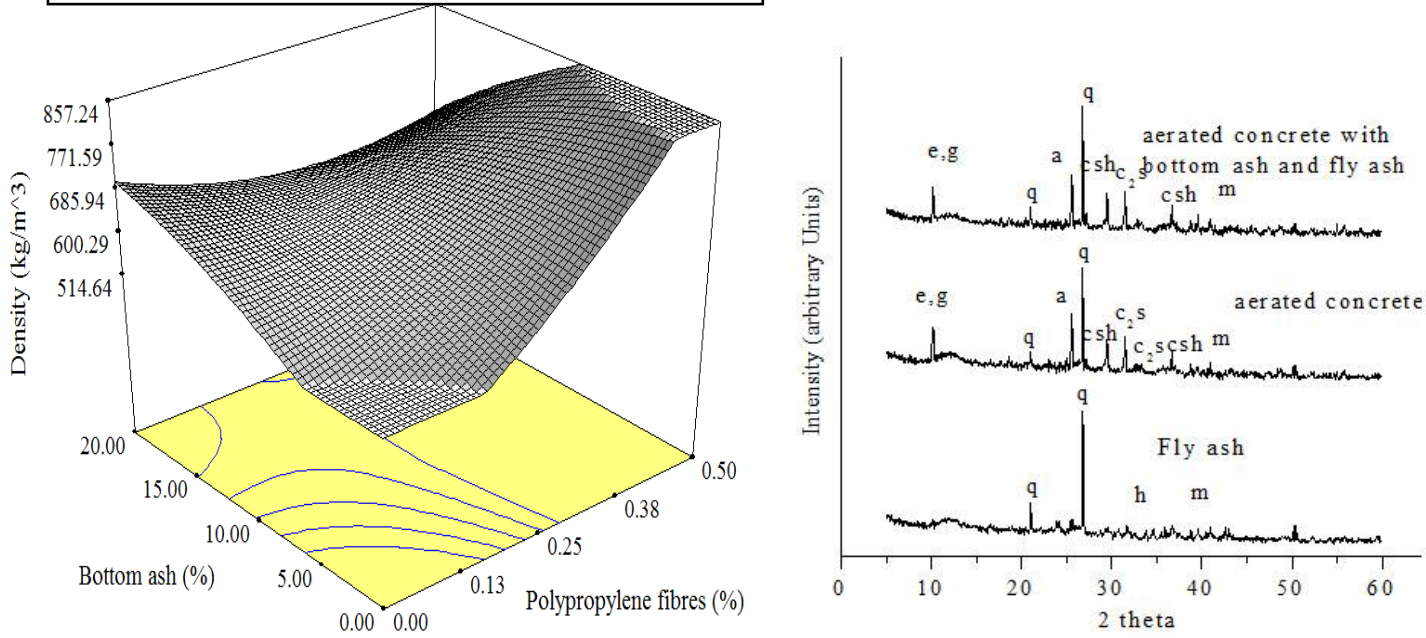

Fig-5 Response surface for density with

Fig-6 XRD of fly ash, conventional fibres and bottom ash aerated concrete and aerated concrete with bottom ash and fly 


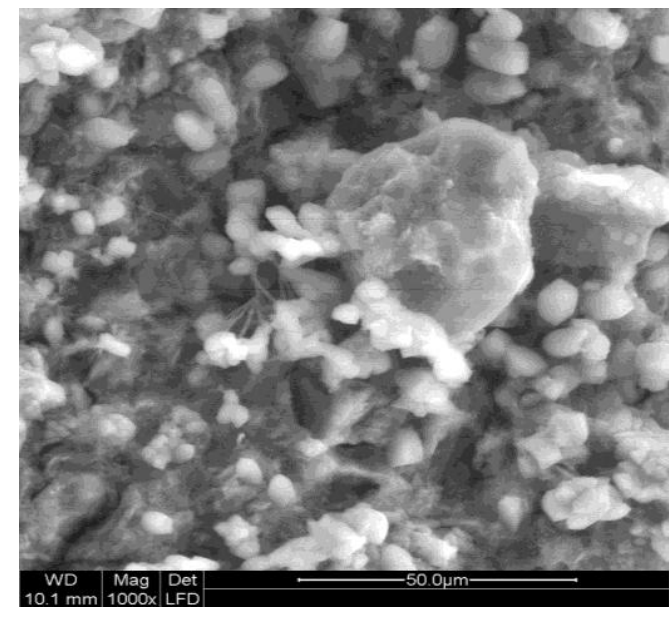

Fig-7(a) SEM images showing Hydration products

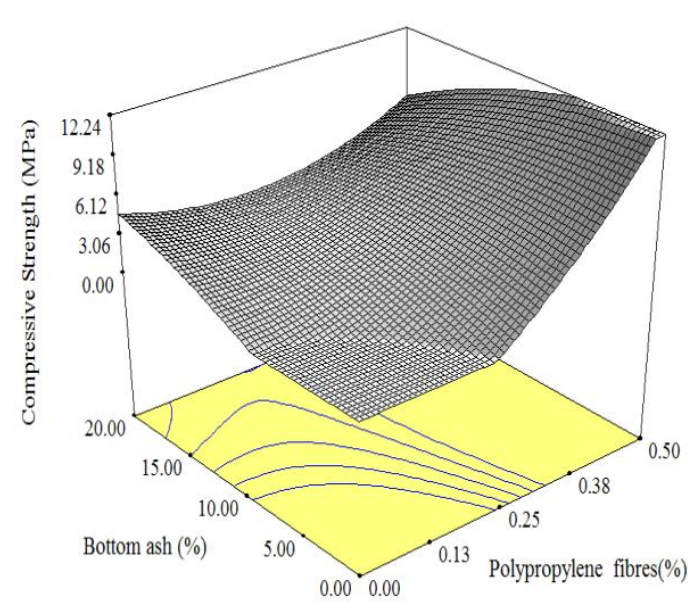

Fig-8 Response surface for compressive strength with fibres and bottom ash

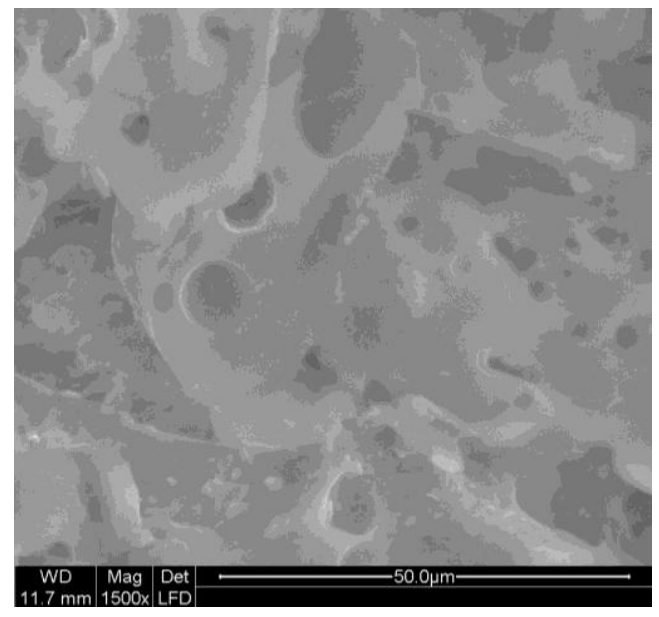

Fig-7(a) SEM images showing isolated air voids

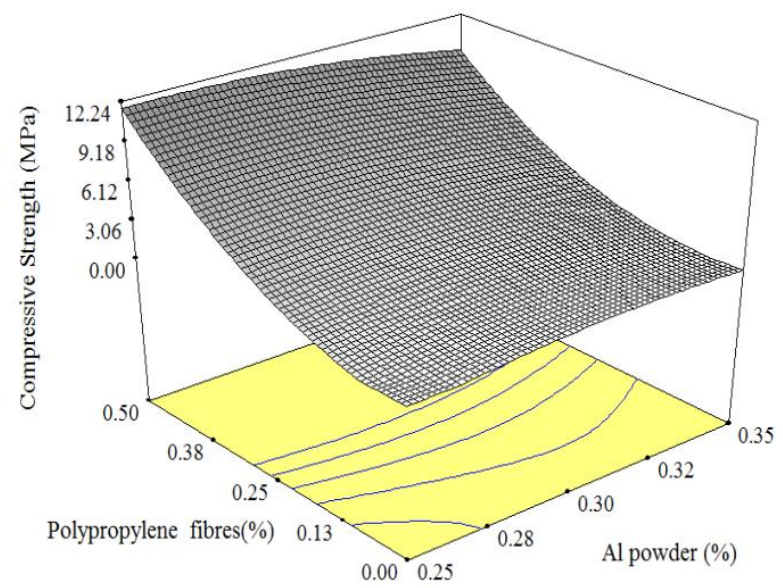

Fig-9 Response surface for compressive strength with fibres and $\mathrm{Al}$ powder

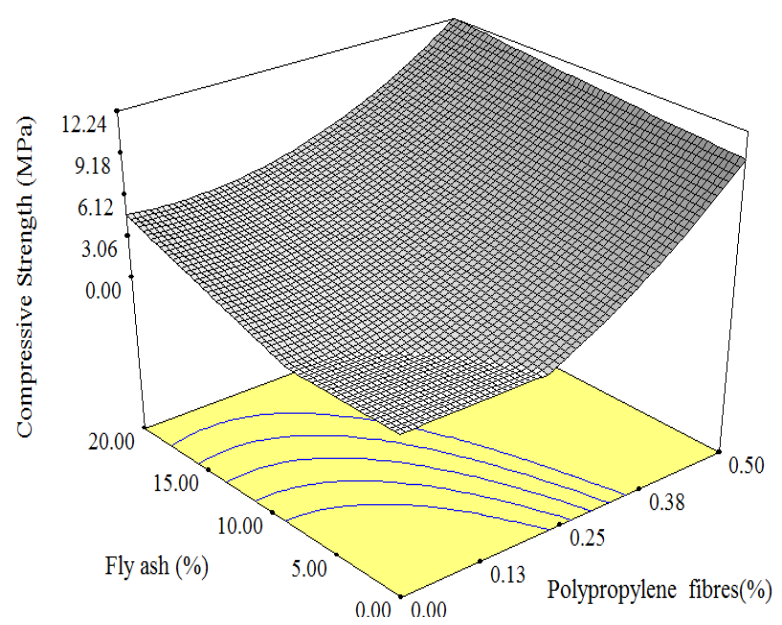

Fig-10 Response surface for compressive strength with fibres and fly ash 

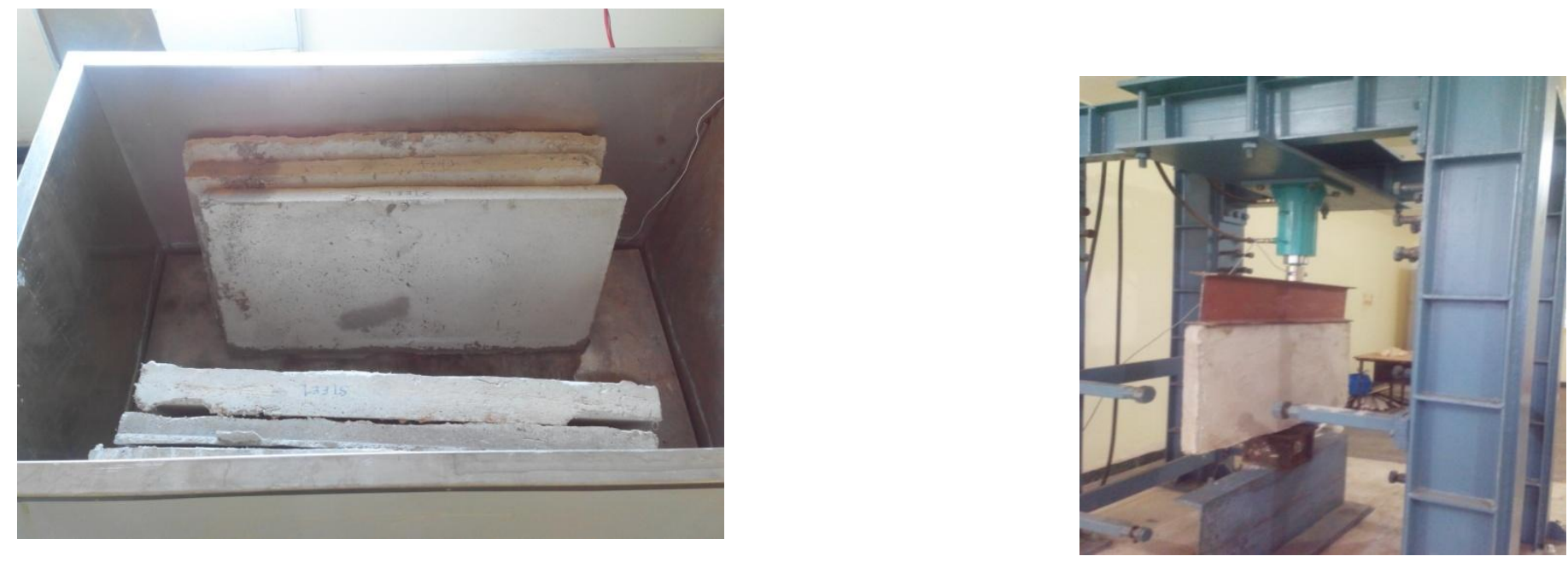

Fig-11 Steam curing of Wall Panels

Fig-12 Testing of Wall Panels

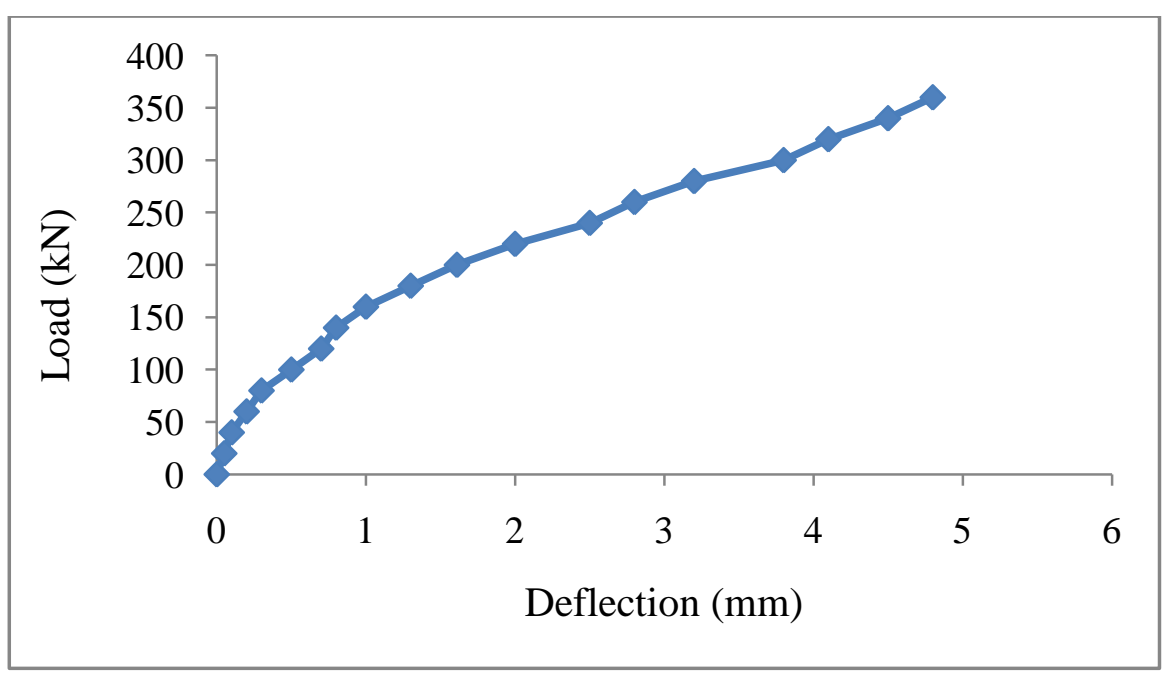

Fig-13 Load - deflection behaviour of the wall panel 